\title{
Brief 40: Nachträgliche Studienbescheinigung von Max Born an Grete Henry(-Hermann) (31.10.1939)
}

University of Edinburgh

Oktober 31st, 1939

\author{
Deparment of Natural Philosophy \\ The University \\ Drummond Street \\ Edinburgh
}

\section{Certificate}

Mrs. G. Henry, former Miss Hermann, has been a student in my department at Goettingen University. She has got a Ph. D. degree in 1925, talking Mathematics (under Professor Emmy Noether) as chief subject, and Physics and Philosophy in addition. In the same year she passed the state examinations for teachers license in the same subjects.

As the documents stating these facts are not accessible to Mrs. Henry I certify the truth of them.

\author{
Max Born, Ph.D., D. Sc. h. r. F. R. S. \\ Tait Professor of Natural Philosophy, \\ University of Edinburgh \\ Former Professor of Mathematical Physics, \\ University of Goettingen, Germany
}

(C) Springer Fachmedien Wiesbaden GmbH, ein Teil von Springer Nature 2019 